\author{
Eduardo Miguez and Maria Tavares
}

\title{
THE N MR STUDY OF THE LATEX EXTRACTED FROM BROSIMUM PARINARIOIDES
}

\author{
Instituto de M acromoleculas Professora Eloisa Mano - UFRJ \\ Centro de Tecnologia, Bloco J - Cidade. Universitaria, Rio de J aneiro, RJ \\ Brasil, CEP 21945-970, CP 68525; mibt@ima.ufrj.br
}

Received: April 04, 2010 / Revised: September 10, 2010 / Accepted J anuary 21, 2011

(C) Miguez E., Tavares M., 2011

\begin{abstract}
In this work we used high-resolution nuclear magnetic resonance (NMR) to identify the major compounds present in the Natural latex named Leite de Amapá, which is extracted from Brosimum paranarioides tree. To do it $1 \mathrm{D}{ }^{1} \mathrm{H}$ and ${ }^{13} \mathrm{C}$ NMR spectra and DEPT techniques were employed. The analysis of spectral data showed that this latex is principally constituted by $\mathrm{cis}$ isoprene, saturated and unsaturated fatty acids and triacylglycerides esters.
\end{abstract}

Keywords: Brosimum paranarioides, Leite de Amapá, NMR, latex.

\section{Introduction}

Latex is the protective fluid contained in tissue beneath the bark of a tree. Natural latexes are complex emulsion in which many substances, such as proteins, polysaccharides, sugars, oils, gums and cis-1,4polyisoprene can be found as major constituents. The latex extracted from Brosimum parinarioides tree found in Amazônia crops is frequently used as food for humble people and it is also used as a popular medicine for treating tuberculosis and asthma [1-4]. Since its uses were known by the scientific community, some studies about this latex started, but no study was done deeply to know the major components present in these types of sample. It is known that nuclear magnetic resonance is very much used to characterize a chemical structure and a molecular dynamic of samples [2-15]. This spectroscopy has many techniques, which differ in pulse sequence that permits us to evaluate both chemical constituents and molecular dynamic, because NMR analyzes the sample in different physical states [2-4, 10-15]. According to the context, this work has a purpose to map the principal components that are responsible for the pharmacological and toxic effects and determine the stability degree of this latex after being kept at environment conditions. For that, we apply solution NMR techniques, employing 1D pulse sequences to evaluate the chemical constituents and solid state techniques, through low field NMR, determining the hydrogen relaxation parameter to accompany the stability degree of the latex, according to the way and time of storage.

\section{Experimental}

\subsection{Latex Extraction}

The latex of Brosimum parinarioides tree was extracted from the trunk using a special knife, and kept in a bottle at room temperature.

\subsection{N M R Analyses}

The Leite de Amapá latex was conditioned to room temperature $(298 \mathrm{~K}) .30 \mathrm{~g}$ were dissolved in $0.6 \mathrm{ml}$ of $\mathrm{CDCl}_{3}$ and added to a $5 \mathrm{~mm}$ NMR tube which was analyzed in a Varian Mercury 300 equipped with a $5 \mathrm{~mm}$ inverse probe to obtain hydrogen $\left({ }^{1} \mathrm{H}\right)$, carbon- $13\left({ }^{13} \mathrm{C}\right)$ and DEPT spectra using the standard pulse sequences of the spectrometer. $2.5 \mathrm{~g}$ were added to $18 \mathrm{~mm}$ NMR tube and it was analyzed in a low field NMR Maran Ultra (Resonance Oxford -UK), operating at $23 \mathrm{MHz}$ for the hydrogen nucleus, to obtain data of spin lattice relaxation time (recycle delay $-180^{\circ}-\tau-90^{\circ}-$ acquisition data) the $90^{\circ}$ pulse of $4.5 \mu \mathrm{s}$ was calibrated automatically by the instrument software. The amplitude of the FID was sampled for twenty $\tau$ data points, ranging from 0.01 to $5000 \mathrm{~ms}$, using 20 data points and 4 scans for each point. The same sample was kept as described above and analyzed six months later; the analysis was carried out at $298 \mathrm{~K}$. The spin-spin relaxation time was determined by CPMG (Carr-Purcell-Meiboom-Gill) technique, using $\tau$ 50 microseconds; recycle delay $5 \mathrm{~s}$ and 4096 scans. The $\mathrm{T}_{2}$ analyses were carried out for one year (twelve months). The relaxation values and relative intensities were obtained by fitting the exponential data with the aid of the program 
WINFIT. Distributed exponential fittings as a plot of relaxation amplitude versus relaxation time were performed by using the software WINDXP. Both WINFIT and WINDXP were commercial programs and come with the low-field NMR spectrometer.

\section{Results and Discussion}

The analyses of low field NMR, employing the proton relaxation time data, allowed us to establish a parameter to study the stability degree of the latex in relation to time of storage at laboratory ambient conditions. Both proton spin-lattice $\left(T_{1}\right)$ and spin-spin $\left(T_{2}\right)$ relaxation parameters were used to detect changes in the molecular structure; water absorption and sample degradation. As it is reported in Table 1 , from $\mathrm{T}_{1} \mathrm{H}$ parameter, three domains were detected: the shortest was related to water absorption, the second was attributed to low molecular compounds and the highest one was associated to rigid molecular domain. However, no change could be observed during the period of sample analyses. Thus, this can be an indication that this parameter was not adequate to this kind of evaluation. According to $\mathrm{T}_{1} \mathrm{H}$ results, the $\mathrm{T}_{2} \mathrm{H}$ relaxation parameter was also investigated and determined for the latex during a period of 12 months (Table 2). According to the $T_{2}$ results an increase of the relaxation time was detected with the increase of time storage that was associated to the changes in the water intra and extracellular interactions, which cause a modification/break of hydrogen linkage, as a consequence of the water diffusion changes, generating latex instability.

Table 1

Values of $T_{1}$ of Leite de Amapá with time storage

\begin{tabular}{|c|c|}
\hline Time of storage & $\mathrm{T}_{1} \mathrm{H}(\mathrm{ms})$ \\
\hline Zero month & $0.1 ; 15 ; 112$ \\
\hline Sixth month & $0.1 ; 15 ; 112$ \\
\hline
\end{tabular}

$\mathrm{T}_{2} \mathrm{H}$ values for Leite de Amapá with time storage

\begin{tabular}{|c|c|}
\hline Time of storage & $\mathrm{T}_{2} \mathrm{H}(\mathrm{ms})$ \\
\hline Zero month & 262 \\
\hline Sixth month & 357 \\
\hline Twelfth month & 599 \\
\hline
\end{tabular}

\subsection{The Evaluation of Constituents by Solution N MR}

The spectra of high field NMR carbon-13 and hydrogen are showed in Fig. 1. They were useful to determinate the majority components of the latex dissolved in chloroform. From the first analysis of the carbon-13 NMR spectrum, three ranges of chemical shift were detected. One from 15 to $60 \mathrm{ppm}$, derived from aliphatic carbons; the second one from 120 to $145 \mathrm{ppm}$ that can be attributed to double bond and/or aromatic region and the third one from 170 to $180 \mathrm{ppm}$, which are derived from carbonyl groups associated with ester components.

The analysis of hydrogen spectrum shows two distinct ranges, the one located from 1 to $2.4 \mathrm{ppm}$, derived from aliphatic chains and the other one with NMR signals varied from 4.5 to $5.5 \mathrm{ppm}$, which are attributed to double bond, discarding the presence of aromatic compounds, which are in accordance with studies done before [1-4, $8,15]$.

According to the NMR ${ }^{1} \mathrm{H}$ and ${ }^{13} \mathrm{C}$ spectra, some classes of substances can be identified. The ${ }^{13} \mathrm{C}$ NMR signals located from 10 to $60 \mathrm{ppm}$ and ${ }^{1} \mathrm{H}$ NMR signals from 1 to $2 \mathrm{ppm}$, belonged to saturated region and were associated with acylglycerols of long chains. The double region was assigned from 100 to $130 \mathrm{ppm}$, in respect to ${ }^{13} \mathrm{C}$ NMR and from 4.5 to $5.5 \mathrm{ppm}$ in relation to ${ }^{1} \mathrm{H}$ NMR signals, which were attributed to cis-isoprene and triacylglycerols and therpenes. The carbonyl region was located at around $170 \mathrm{ppm}$ that is associated with the ester group. From the analyses of these NMR signals the majority of components of the latex is derived from: cisisoprene, saturated and unsaturated fatty acids and triacylglycerides esters. As minor components terpenoid compounds were detected and the structure of acyl lupeol ester [2] was identified. The same type of components has been characterized in a similar sample, studied before [2-4, 15]. This is a well known substance that is reported as an anti-inflammatory and anti-arthritic one [3] (Fig. 2). An acetyl ursan terpenoid was also identified and its chemical structure can be seen in Fig. 3. The cis-isoprene (Fig. 4) has their signals assigned and listed in Table 3. DEPT technique (Fig. 5) was also used to confirm the methyl and methylene groups (Table 4), which normally cannot be easily distinguished when a lot of signals are located in the same spectral region (Table 5).

Table 3

\section{Chemical assignments of $c$ is-isoprene obtained from ${ }^{13} \mathrm{C}$ NMR solution spectrum}

\begin{tabular}{|c|c|}
\hline$\delta, \mathrm{ppm}$ & Carbon type \\
\hline $21-23$ & $\mathrm{CH}_{3}$ \\
\hline 109 & $=\mathrm{CH}_{2}$ \\
\hline $120-126$ & $=\mathrm{CH}$ \\
\hline $134-151$ & $=\mathrm{C}$ \\
\hline
\end{tabular}



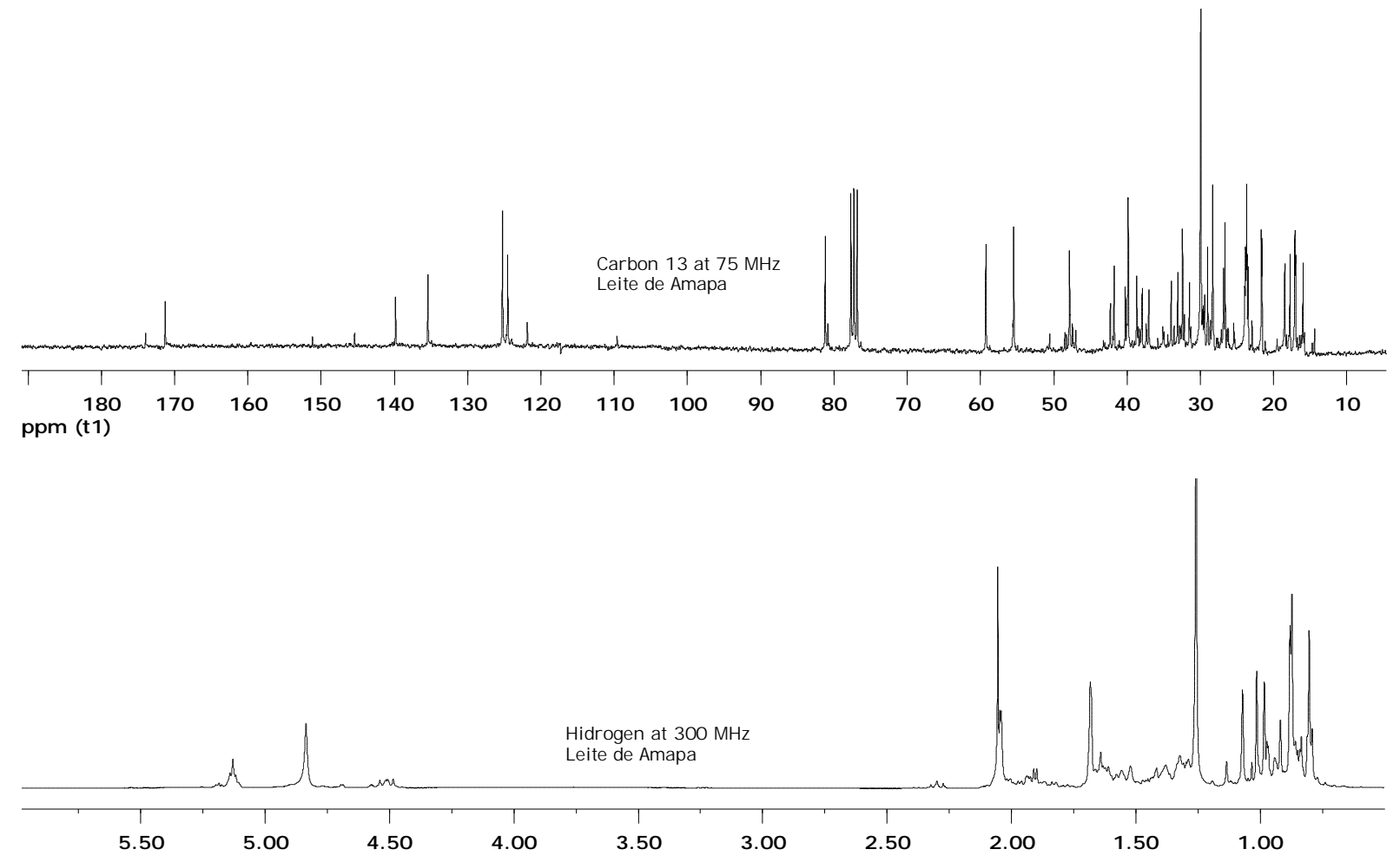

ppm (t1)

Fig. 1. ${ }^{13} \mathrm{C}$ NMR spectrum of Brosimum parinarioides (top) and ${ }^{1} \mathrm{H}$ NMR spectrum of Brosimum parinarioides (bottom)<smiles>C=C(C)[C@@H]1CCC2(C)CC[C@]3(C)C(CCC4(C)C5CCC6(C)C(OC(=O)CC)CC[C@]6(C)C5CCC43C)C12</smiles>

Fig. 2. Terpenoid structure, acyl lupeol ester<smiles>C=CC=CC</smiles>

Fig. 4. Cis-isoprene structure

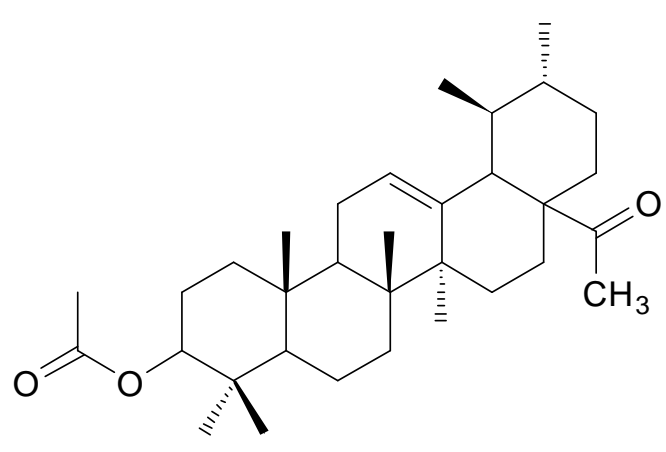

Fig. 3. Terpenoid structure, acetyl ursan ester 


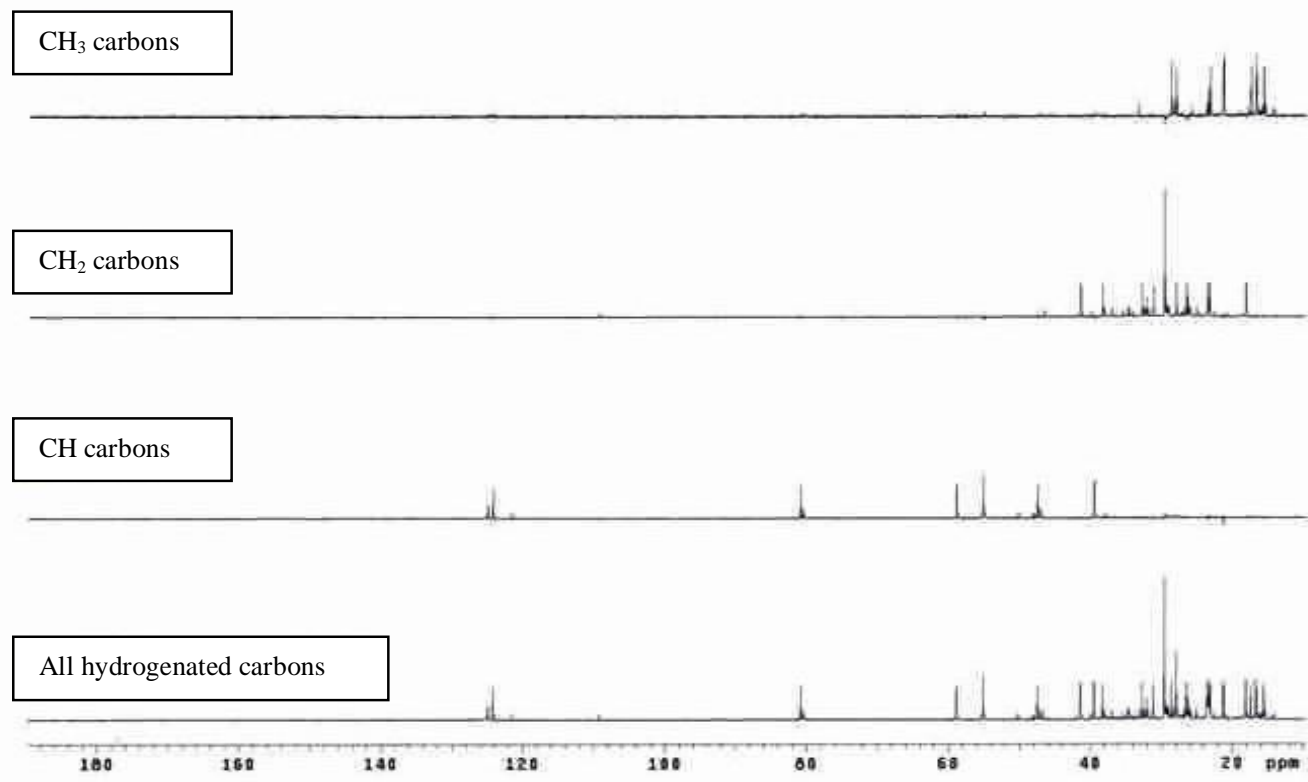

Fig. 5. DEPT spectrum of latex in $\mathrm{CDCl}_{3}$

Table 4

Carbon-13 assignment of saturated and unsaturated fatty acids, triacylglicerols

\begin{tabular}{|c|l|}
\hline$\delta, \mathrm{ppm}$ & \multicolumn{1}{|c|}{ Carbon-13 type } \\
\hline 170 & $\mathrm{C}=\mathrm{O}-$ from the ester \\
39.8 & $\mathrm{CH}-$ from the branch \\
38.3 & $\mathrm{CH}-$ from the branch \\
34.8 & $\mathrm{CH}-$ from the main chain \\
32.7 & $\mathrm{CH}-$ from the branch \\
32.0 & $\mathrm{CH}_{2}-$ from the long chain \\
31.1 & $\mathrm{CH}_{2}-$ from the long chain \\
29.5 & $\mathrm{CH}_{2}-$ from the main chain \\
28.6 & $\mathrm{CH}_{2}-$ from the main chain \\
27.8 & $\mathrm{CH}_{2}-$ from the main chain \\
26.5 & $\mathrm{CH}_{2}-$ from the main chain \\
26.3 & $\mathrm{CH}_{2}-$ from the main chain \\
20.4 & $\mathrm{CH}_{2}-$ from the branch \\
14.8 & $\mathrm{CH}_{2}-$ from the long branch near to $\mathrm{CH}_{3}$ \\
\hline
\end{tabular}

\section{Table 5}

Chemical assignments from DEPT spectrum

\begin{tabular}{|c|c|}
\hline$\delta$, Carbon-13,ppm & DEPT \\
\hline 1 & 2 \\
\hline 173.6 & $\mathrm{Cq}$ \\
170.9 & $\mathrm{Cq}$ \\
12.8 & $\mathrm{CH}$ \\
124.1 & $\mathrm{CH}$ \\
121.4 & $\mathrm{CH}$ \\
109.2 & $\mathrm{CH}_{2}$ \\
\hline
\end{tabular}

Continuation of Table 5

\begin{tabular}{|c|c|}
\hline 1 & 2 \\
\hline 80.8 & $\mathrm{CH}$ \\
80.4 & $\mathrm{CH}$ \\
58.8 & $\mathrm{CH}$ \\
55.2 & $\mathrm{CH}$ \\
55.0 & $\mathrm{CH}$ \\
48.1 & $\mathrm{CH}$ \\
47.8 & $\mathrm{CH}$ \\
41.3 & $\mathrm{CH}$ \\
39.5 & $\mathrm{CH}$ \\
39.4 & $\mathrm{CH}$ \\
38.3 & $\mathrm{CH}_{2}$ \\
32.7 & $\mathrm{CH}_{2}$ \\
32.0 & $\mathrm{CH}_{2}$ \\
31.1 & $\mathrm{CH}_{2}$ \\
29.5 & $\mathrm{CH}_{2}$ \\
28.6 & $\mathrm{CH}_{3}$ \\
27.9 & $\mathrm{CH}_{2}$ \\
27.9 & $\mathrm{CH}_{3}$ \\
26.4 & $\mathrm{CH}_{2}$ \\
26.2 & $\mathrm{CH}_{2}$ \\
23.4 & $\mathrm{CH}_{2}$ \\
23.3 & $\mathrm{CH}_{3}$ \\
23.2 & $\mathrm{CH}_{2}$ \\
23.0 & $\mathrm{CH}_{3}$ \\
21.3 & $\mathrm{CH}_{3}$ \\
21.2 & $\mathrm{CH}_{3}$ \\
18.1 & $\mathrm{CH}_{2}$ \\
17.3 & $\mathrm{CH}_{3}$ \\
16.7 & $\mathrm{CH}_{3}$ \\
16.6 & $\mathrm{CH}_{3}$ \\
15.6 & $\mathrm{CH}_{3}$ \\
\hline & \\
\hline
\end{tabular}




\section{Conclusions}

The analyses of the latex by high resolution spectra made possible to identify the majority compounds and especially the minor components from secondary metabolism, which are known to be responsible by the pharmacological and toxicological effects. The analyses of low field data indicated the stability of the latex up to six months. The sum of all data is that NMR is a very useful tool to study this kind of samples.

\section{Acknowledgements}

The authors would like to thank you CNPq, FAPERJ and CAPES.

\section{References}

[1] Nascimento A.: MSc thesis, Universidade do Amazonas, Manaus, Amazonas, Brasil 1999.

[2] Nascimento A., Tavares M. and Nascimento R.: Int. J. Polym. Mat., 2007, 56, 31 .

[3] Nascimento A. and Tavares M.: Int. J. Polym. Mat., 2007, 56, 115. [4] Sarwata S. et al.: Pharmacol. Res., 2001, 43, 132.

[5] Harris R.: The Fifth Int. Conf. on Application of Magnetic Resonance in Food Science, Aveiro, Portugal 2000, I, 1.
[6] Gil A.:ibid, 43.

[7] Sacchi R.: ibid, 20.

[8] Tang H. and Hill B.: Biomacromolecules, 2003, 4, 1269.

[9] Silva E., Bathista A., Tavares M. et al.: J. Food Sci.Agric., 2005, 85, 2269.

[10] Rodrigues T., Tavares M., Preto M. et al.: Int. J. Polym. Mat., 2008, 57, 1119.

[11] Silva E., Tavares M., Miguez E. and Nogueira J.: ibid, 594.

[12] Conte P., Spaccini P. and Piccolo A.: Prog. Nuc. Mag. Res. Spec., 2004, 44, 215.

[13] Costa P., Tavares M., Silva E. et al.: Int. J. Polym. Mat., 2007, 56, 1135 .

[14] Silva E., Tavares M. and Nogueira J.: ibid, 1119.

[15] Silva E., Tavares M. and Nogueira J.: J. Nano Res., 2009, 4, 117.

\section{ДОСЛІДЖЕННЯ МЕТОДОМ ЯМР ЛАТЕКСНОЇ ВИTЯЖКИ 3 BROSIMUM PARINARIOIDES}

Анотація. 3 використанням ядерного магнітного резонансу (ЯМР) з високим розрішенням ідентифіковано основні сполуки, присутні в природному латексі Leite de Aтара, який видобувасться з дерева Brosimuт paranarioides. Застосовано $1 D^{l},{ }^{13}$ С ЯМР і DEPT методи. За допомогою спектрального аналізу показано, щэо основними складовими досліджсуваного латексу є ичис-ізопрен, насичені та ненасичені жсирні кислоти та естери триацилглічеридів.

Ключові слова: Brosimum paranarioides, Leite de Amapa, ЯМР, латекс. 